\title{
BACTERIAL COMMUNITY SHIFTS OF A HIGH MOUNTAIN LAKE IN RESPONSE TO VARIABLE SIMULATED CONDITIONS: AVAILABILITY OF NUTRIENTS, LIGHT AND OXYGEN
}

\author{
MUNTI YUHANA ${ }^{1}$, THOMAS HORATH ${ }^{2}$ AND KURT HANSELMANN ${ }^{2}$ \\ 'Department ofAguamlture, Faculty of Fisheries and Marine Science, Bogor Agricultural University, \\ Kampus IPB Darmaga 16680 Bogor, Indonesia. \\ ${ }^{1}$ Department of Microbiology, Institute of Plant Biology, University of Zurich, Zollikerstrasse 107, 8008 \\ Ziirich, Switzerland.
}

\begin{abstract}
We studied bacterial population composition shifts by exposing natural water samples to variable simulated environmental conditions. The samples were taken from Lake Jori XIII (2640 m a.s.l), an oligo-to mesotrophic cold freshwater lake, located in the eastern Swiss Alps. The Jori lakes are characterized as remote, unpolluted high mountain lakes with a long period of ice cover and typically low nutrient concentrations. Culture independent techniques (PCR-based analyses) were used for detection and molecular characterization of a large number of bacteria most of which are still uncultivable. Bacterial community shifts over three ecological conditions (nutrients, light and oxygen availability) were detected by using Temporal Temperature gradient Gel Electrophoresis (TTGE) of a PCR-amplified part of the 16S rRNA gene. The bacterial populations responded differently to the variable conditions, as revealed by TTGE pattern shifts during the experiment.
\end{abstract}

Key words: Temporal Temperature gradient Gel Electrophoresis (TTGE), ARB, small subunit ribosomal RNA gene (SSU rRNA gene), alpine freshwater lake JOri XIII, PCR

\section{INTRODUCTION}

Lake Jori XIII is located in Canton Graubiinden, Switzerland. This lake has a maximum depth of $10.9 \mathrm{~m}$ and its surface area is approximately $15400 \mathrm{~m}^{2}$. Lake XIII presently is one among 22 medium and small lakes in the Jori catchment. Some of them are several thousand years old, and others were formed when the glacier retreated during the last 150 years. The habitats are still evolving. They are situated in the eastern part of Swiss Alps, at 46 $46^{\prime} \mathrm{N}$ latitude and 9 $9^{\circ} 8^{\prime} \mathrm{E}$ longitude, at altitudes between $2489 \mathrm{~m}$ to $2750 \mathrm{~m}$ above sea level. The iron-rich area is almost free of vegetation. Several lakes (for example Lakes I, II and III) are still influenced by streamlets from the melting glacier, whereas many others, which are mostly situated on higher places, are no longer under glacier influence, including Lake Jori XIII (Figure 1).

Remote, unpolluted high mountain lakes are ecosystems in which their hydrochemical conditions are characterized by extremely variable fluctuations and often sudden changes. These intrannual and interannual environmental conditions 


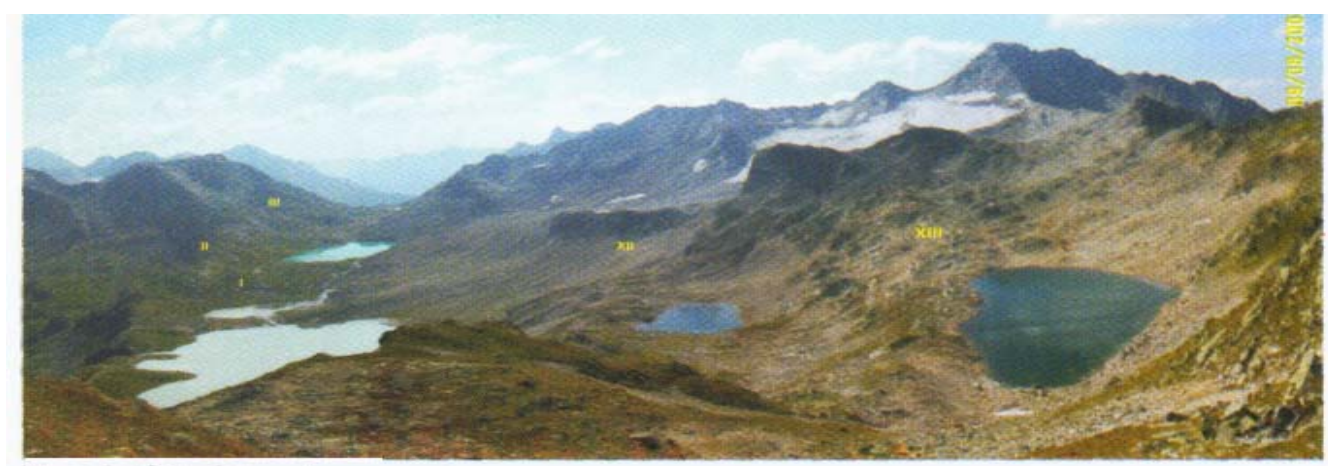

Photo by Kurt Hanselmann

Figure 1. View of Lakes Jori I, II, III, XII and XIII during summer, ice-free period.

can be related to the atmospheric or climate variability. The alpine lakes can be considered as relatively simple aquatic ecosystems with short food chains, restricted environmental variables and low species diversity.

Organisms living in these habitats are challenged by harsh temperatures (below freezing to $+15^{\circ} \mathrm{C}$ maximally), by seasonal and diurnal radiation differences between darkness and high levels of UV, by nutrient deprivation and bursts during snow melt phases, and by anoxia and darkness in the hypolimnion below a long lasting ice cover. During the short summer period, the epilimnion experiences high diurnal temperature fluctuations, strong light penetration and high UV radiation (Bothwell et ol. 1994). Maximal water temperature during this period can reach $15^{\circ} \mathrm{C}$ but it could suddenly drop to $0^{\circ} \mathrm{C}$ in case of snow fall.

Bacteria are known to thrive under extremely broad-range conditions including such that would kill other organisms. They are further able to perform various metabolic processes, and their capabilities are more diverse compared to higher organisms. Therefore, we focused on the adaptation of the bacterial community in this extreme habitat. We were interested in how the bacterial population composition shifts under fluctuating environmental conditions. Normally, in the environments which get exposed to diurnal changes and annual variation in physicochemical and trophic conditions, the communities are forced to adapt quickly.

The bacterioplankton community structure changes were studied in vitro by simulating three environmental determinants i.e. light, oxygen, and nutrients. Temporal Temperature gradient Gel Electrophoresis (TTGE) has been used to follow the bacterial community composition changes. TTGE is a method which does not require a cloning step for profiling microbial populations, therefore, it is a fast monitoring method. The small subunit (SSU) ribosomal RNA gene is widely used as a comparative phylogenetic marker (Ward et al. 1990; Muyzer et al. 1993). The ribosomal RNA gene has several features that make it an ideal phylogenetic marker. First, as the backbone inside the ribosome it is ubiquitous in the living world. 
Further it has the same function in all organisms, it is functionally homologous. Also it is more sensitive to mutations than most of the other genes since its gene product is used directly without any further translation into a protein where some mutations could keep silent. The gene sequence itself has regions of broad homology but also of heterogeneity compared with different organisms (it is moderately well-conserved) which makes it easy to align it in almost all levels of phytogeny. Concerning the nucleic acid length of the rRNA gene, the sequence of the SSU rDNA has the advantage that it is long enough for a reasonable alignment but quite shorter than the sequence of the large subunit rDNA (LSU rRNA gene) which makes it cheaper and faster to work with. The community shifts were monitored by comparing the changes of DNA fingerprints of PCR-generated 16S rDNA fragments in a TTGE gel. The electrophoretic separation of the community DNA molecules in TTGE is based on the temperature gradient. The separated bands can then be excised, PCR-amplified, and sequenced to identify the members of the community. This technique has been applied already for assessment and monitoring of bacterioplankton community dynamics in diverse aquatic environments (Bosshard et al. 2000; Pearce 2000; Casamayor et al. 2002).

The three environmental determinants chosen - nutrient supply, light, and redox condition - strongly affect biological processes. Combinations of these factors were used for in vitro simulations. The results illustrate the population flexibility and further support the validity of the selective adaptation hypothesis for ecosystems under harsh and highly variable environmental conditions (Elena and Sanjuan 2003).

\section{MATERIALS AND METHODS}

\section{Sample collection}

Sampling was carried out in late autumn in October 2002 in Lake Jb'ri XIII. Samples were taken from the lake water column, at 5 different depths of $1,3,5,7$, and 9 meters, respectively. Water samples were collected with a $500 \mathrm{ml}$ Niskin sampler. The sampler was pre-rinsed with the lake water from the desired depths. The actual water samples were filled in sterilized $500 \mathrm{ml}$ glass bottles and were kept at low temperature in a cooling box for transportation.

Sub samples for the experiments under the different conditions were taken in the laboratory (Table 1). Volumes of $100 \mathrm{ml}$ for each experiment were placed aseptically in sterile $200 \mathrm{ml}$ glass bottles. All samples were incubated at $4^{\circ} \mathrm{C}$ under a combination of the following conditions: with or without additional nutrients, in the light and in the dark, with oxygen (stirring) and anoxically (Figure 2). The final concentration after adding nutrients was 10 fold diluted Luria Bertani (LB) medium consisting of: tryptone $0.5 \mathrm{~g} \mathrm{I}^{\mathrm{I}^{1}}$, yeast extract $1.0 \mathrm{~g} \mathrm{I}^{\mathrm{I}^{1}}$, and $\mathrm{NaCl} 0.5 \mathrm{~g} \mathrm{I}^{\mathrm{I}^{1}}$. The $\mathrm{pH}$ was adjusted to 7.2. A sample set was incubated in the dark (the bottles were wrapped in aluminum foil). Samples that needed light were incubated under two 15 Watt tube lamps (Osram) i n a $30 \times 30 \times 70 \mathrm{~cm}^{3}$ refrigerator, with continuous illumination. Aerobic incubation was done on stirrer plates. Each bottle of this 
Table 1. Experimental overview of the community changes in vitro.

\begin{tabular}{|c|c|c|c|c|c|c|c|c|}
\hline \multirow{3}{*}{$\begin{array}{l}\text { Sample }^{\text {a) }} \text { from depth } \\
(\mathrm{m})\end{array}$} & \multicolumn{4}{|c|}{ Nutrients added $^{b)}$} & \multicolumn{4}{|c|}{ No nutrients } \\
\hline & \multicolumn{2}{|c|}{ dark } & \multicolumn{2}{|c|}{ light } & \multicolumn{2}{|c|}{ dark } & \multicolumn{2}{|c|}{ light } \\
\hline & oxic & anoxic & oxic & anoxic & oxic & anoxic & oxic & anoxic \\
\hline 1 & $*$ & & * & 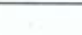 & $\bullet$ & & * & \\
\hline 3 & & $*$ & & - & & - & & * \\
\hline 5 & * & & * & & - & & * & \\
\hline 7 & & $*$ & & * & & * & & * \\
\hline 9 & * & & * & & * & & * & \\
\hline
\end{tabular}

experiments carried out

1" October, 2002

b) 10-fold diluted LB medium

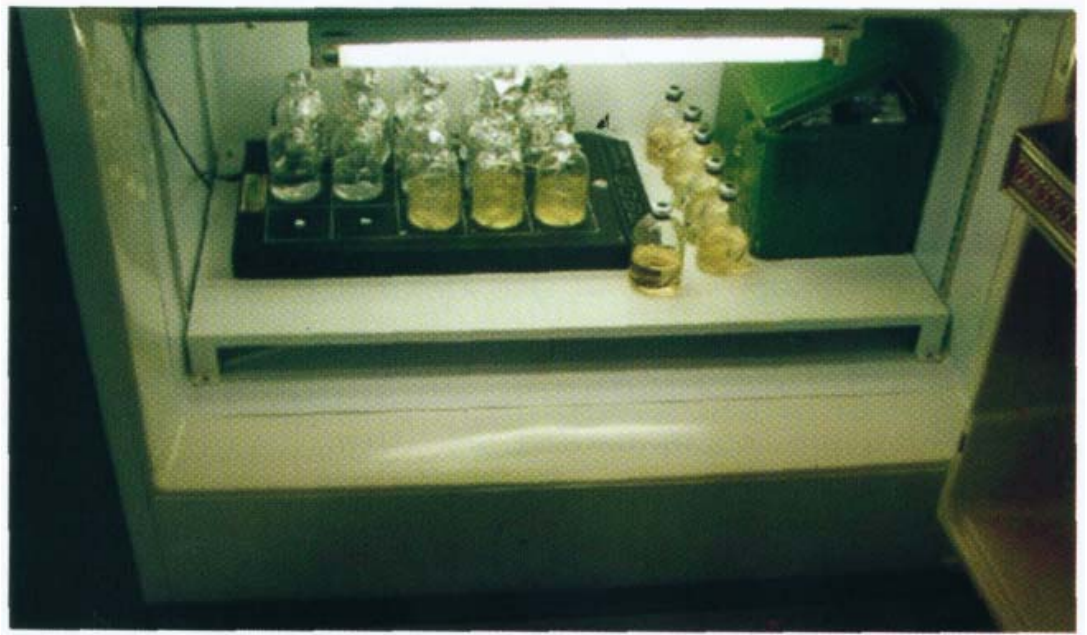

Figure 2. Incubation of samples treated under a series of different simulated conditions at $4^{\circ} \mathrm{C}$.

treatment was stirred continuously using a magnetic bar and the bottles were covered by sterile cotton plugs. For anoxic treatment, the bottles were purged with $\mathrm{O}_{2}$-free $\mathrm{N}_{2}$ gas, completely filled and tightly sealed. Resazurin was used as redox indicator in the anaerobic cultures.

\section{Nucleic acid extraction, PCR, and TTGE analysis for community profiling}

Preparation for DNA extraction of initial samples (without treatment) was processed directly in the field laboratory. Water samples of $75 \mathrm{ml}$ were filtered 
Bacterial community shifts - M. Yuhana et al.

aseptically through 0.22 fim pore size filters (Millipore GVWP, $25 \mathrm{~mm}$ in diameter) using a sterile syringe and a "Swinnex ${ }^{\circledR "}$ disc filter holder (Millipore, SXOO 025 00). The filters were placed in sterile $1.5 \mathrm{ml}$ tubes and kept at $-20^{\circ} \mathrm{C}$ until further processing, i.e. DNA extraction, PCR amplification and TTGE analyses.

After 2 weeks of incubation, the cultures were harvested for total genomic DNA extraction, PCR amplification, and further TTGE analysis. Cells were collected by filtration using 0.22 urn pore size filters (Millipore, GVWP, $25 \mathrm{~mm}$ in diameter). The sample quantity varied, depending on the turbidity of the culture. Normally, 40 to $50 \mathrm{ml}$ from the treatments with nutrients and $75 \mathrm{ml}$ from cultures without added nutrients were filtered.

Samples were treated applying protocol B of the Qiagen DNeasy® Tissue Kit for Gram positive bacteria with an additional bead beating lysis step. The microorganisms on the filters were rinsed with lysis buffer and further processed according to the Qiagen protocol. The cells were lysed with lysozyme and disrupted physically by bead beating. Bead beating was done by adding $100 \mathrm{mg}$ of glass beads ( $0.1 \mathrm{~mm}$ in diameter) to each tube and shaking at $80 \%$ of maximum speed in a Retsch MM2000 bead beater (F. Kurt Retsch GmbH \& Co. KG, 42781 Haan, Germany) for 1 min. The extracted DNA was diluted in $100 \wedge 1$ sterilized $\mathrm{H}_{2} \mathrm{O}$. Tubes containing extracted genomic DNA were stored at $-20^{\circ} \mathrm{C}$ until further processing.

To amplify the 16S rRNA gene fragments from the total community DNA, we used the general bacterial primers 27f (= S-D-Bact-0008-b-S-20; 5'-AGA GTT TGA TCM TGG CTC AG) and 1524r (= slightly modified 1525r, S-D-Bact-1524-a-A-18; 5'-AAG GAG GTG ATC CAR CCG) (Lane 1991). PCR reactions were prepared in a volume of $25 \mathrm{ul}$, containing (final concentration): $\mathrm{dH}_{2} \mathrm{O}$, Taq buffer (Ix) (Sigma), $0.1 \mathrm{mg} \mathrm{ml}{ }^{1}$ DNase-free bovine serum albumin (Amersham, Pharmacia Biotech Inc.), $0.2 \mathrm{mM}$ dNTPs, $200 \mathrm{nM}$ of each primer, $40 \mathrm{U} \mathrm{ml}^{1}$ Taq Polymerase (Sigma), and approximately 50-100 ng template DNA. PCR was performed with a Techne Thermocycler (Techne LTD, Duxford Cambridge, U.K.).

PCR was run under the following conditions: initial denaturation at $94^{\circ} \mathrm{C}$ for 130 sec. The next steps were $10 \mathrm{cycles}$ of $94^{\circ} \mathrm{C}$ for $15 \mathrm{sec}, 63^{\circ} \mathrm{C}$ for $30 \mathrm{sec}$ and lowering the temperature by $0.5^{\circ} \mathrm{C}$ in every cycle (touch down), then $72^{\circ} \mathrm{C}$ for $80 \mathrm{sec}$ with increasing the duration by 1 sec every cycle. These steps were followed by 20 cycles of $94^{\circ} \mathrm{C}$ for $15 \mathrm{sec}, 56^{\circ} \mathrm{C}$ for $30 \mathrm{sec}, 72^{\circ} \mathrm{C}$ for 90 sec with increasing the period by 1 sec every cycle followed by a final extension step at $72^{\circ} \mathrm{C}$ for $10 \mathrm{~min}$. PCR products were analyzed by electrophoresis in a $1 \%$ agarose gel and $0.5 \mathrm{x}$ TAB running buffer [20 mM Trizma base, $10 \mathrm{mM}$ Glacial acetic acid, and $1 \mathrm{mM} \mathrm{Na} \mathrm{N}_{2}$ EDTA]. First PCR amplifications yielded approximately 1'500 bp length of the 16S rRNA gene (data not shown).

The primary PCR products were used as templates for the nested PCR. This method was used to increase the sensitivity and signal strength of the PCR amplification. Universal primers $357 \mathrm{f}$ (slightly modified) (= S-D-Bact-341-b-S-17; 5'-CCT ACG GGA GGC AGC AG) and GC-907r (= GC-Univ-907-a-A-20; 5'-CGC CCG CCG CGC GCG GCG GGC GGG GCG GGG GCA CGG GGG G CCG TCA ATT CMT TTR AGT TT) (Lane 1991; Muyzer et al. 1998) were used to amplify 
the 16S rRNA gene fragments. PCR was performed with initial denaturation at 94' for 5 min, followed by $75^{\circ} \mathrm{C}$ for $15 \mathrm{sec}$. The next steps were 20 cycles of $94^{\circ} \mathrm{C}$ f $20 \mathrm{sec}$, annealing at $65^{\circ} \mathrm{C}$ lowered by $0.5^{\circ} \mathrm{C}$ every cycle- for $30 \mathrm{sec}$ (touch dowr and elongation temperature $72^{\circ} \mathrm{C}$ for $1 \mathrm{~min}$. These steps were followed by $15 \mathrm{cycl}<$ of $94^{\circ} \mathrm{C}$ for $20 \mathrm{sec}, 52^{\circ} \mathrm{C}$ for $30 \mathrm{sec}, 72^{\circ} \mathrm{C}$ for $70 \mathrm{sec}$, and a final extension step ; $72^{\circ} \mathrm{C}$ for 10 min. Nested PCR amplification yielded 16S rRNA gene fragments c approximately 560 bp length (Figure 3).

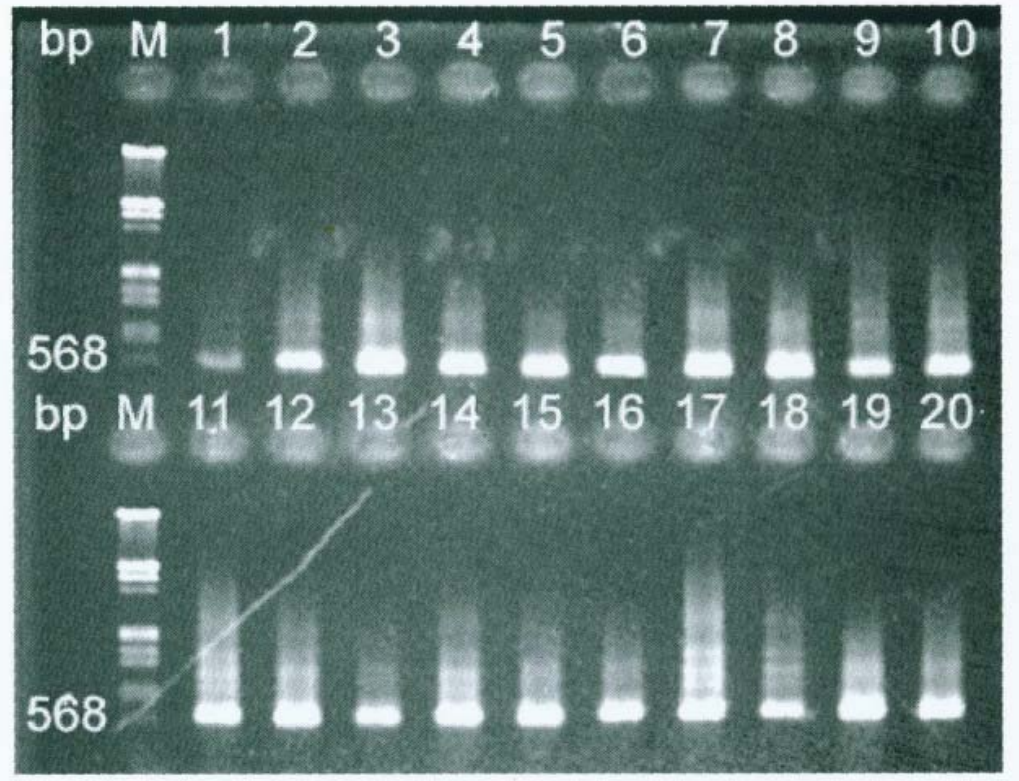

Figures. Products after nested PCR with 357f and GC-907r of the 16S rRNA gene fragments. Only a part of the PCR products from several samples in this study is shown. M: Marker (A DNA digested with EcoRl/HimllU).

(1-5: samples from depth $1 \mathrm{~m}$; 1: initial, 2: HDO, 3: HLO, 4: NDO, 5: NLO; 6-10: samples from depth 3 m, 6. initial, 7: HDA, 8: HLA, 9: NDA, 10: NLA, 11-15: samples from depth 5 m; 11: initial. 12: HDO, 13: HLO. 14: NDO, 15: NLO; 16-20: samples from depth 7 m, 16: initial, 17: HDA, 18: HLA, 19: NDA, 20: NLA).

Initial: initial population, before treatments were applied. $\mathrm{H}$ : 10 -fold diluted LB medium added, $\mathrm{N}$ : no nutrients added, D: incubation in the dark, L: incubation in the light, A: anoxic condition, O: oxic condition. 
TTGE was carried out in a DCode ${ }^{\mathrm{TM}}$ Mutation Detection system (Bio-Rad iboratories). $10 \mathrm{ul}$ of the PCR samples and $10 \mathrm{ul}$ of $2 \mathrm{x}$ loading buffer $(70 \%$ [v/v] ycerol, $0.05 \%$ [w/v] bromophenol blue) were loaded onto $6 \%$ polyacrylamide gels :rylamide: N,N'-methylene bis-acrylamide 37.5:1 [w/w]; $7 \mathrm{M}$ urea, Ix TAB). The Is were run at temperatures starting at $54^{\circ} \mathrm{C}$ and raising to $64^{\circ} \mathrm{C}$, temperature ramp te was $+1.1^{\circ} \mathrm{C} \mathrm{h}{ }^{11}$, the voltage was $90 \mathrm{~V}(4.0 \mathrm{~V} / \mathrm{cm})$, and running time was about 9 The gels were stained in $1 \mathrm{ng} \mathrm{ml}{ }^{11}$ ethidium bromide solution for $15 \mathrm{~min}$, stained in water for 45 min, visualized, and photographed under UV insillumination (X = 312 run).

\section{•quencing of the 16S rRNA genes from PCR-TTGE bands and phylogenetic ee construction}

The representative bands of the dominant bacteria which appeared distinctly in FGE gels were excised and DNA was recovered by putting the gel fragments gether with $20 \mathrm{ul} \mathrm{of} \mathrm{H}_{2} \mathrm{O}$ into a $1.5 \mathrm{ml}$ tube, freezing twice, and taking the .pernatant. PCR amplification was performed by using $341 \mathrm{f}$ and the non-GC-907r imers. PCR products were bidirectionally sequenced using ABI Prism ${ }^{\circledR}$ Big Dye $^{\mathrm{TM}}$ !.0 (Applied Biosystems). The PCR products were purified by centrifugation in icrocon filter devices (Microcon YM 100, Millipore, Bedford, Mass., USA), and ere used for a 10 ul-single PCR reaction: 5 to 20 ng DNA template, 3 (Jl Big Dye Applied Biosystems) and 3 |al of $1.5 \mathrm{uM}$ primer were used. After the sequencing 3R, the products were purified with Sephadex G-50 (Amersham, Pharmacia iotech $\mathrm{AB}$ ) and loaded onto the sequencing machine (ABI Prism 377 DNA squencer).

The BLAST Search tool available from NCBI (http://www.ncbi.nlm.nih.gov/ ast) (Altschul et al, 1998) was used to list the closest neighbors of the sequences, he new 16S rRNA gene sequences were imported to the SSU rRNA database :trieved from the Technical University of Munich (release January 2004) using the RB phylogeny program (http://www.arb-home.de/) (Ludwig et al. 2004) and ligned automatically employing the Fast Aligner VI.03 of the ARE software nvironment. Subsequently the alignment was corrected manually according to the jcondary structure. The sequences were then added to the general tree of the ARB SU rRNA database by calculating distances with a maximum-parsimony algorithm nd using the appropriate SAI (Sequence Associated Information) filters.

\section{RESULTS AND DISCUSSION}

During the short summer period and autumn, the lake was homothermic i.e. the ike water masses were completely mixed. Therefore, the physical and chemical larameters of the lake water column did not differ much among various depths Table 2). The initial TTGE profile from depth of $1 \mathrm{~m}$ is the same as those from lepths of $3 \mathrm{~m}, 5 \mathrm{~m}, 7 \mathrm{~m}$, and $9 \mathrm{~m}$. The community patterns of Lake JQri XIII differ 
Generally, it can be seen that incubations under high nutrient conditions showed fewer bands than the initial community and also fewer when compared to those without nutrients addition. Low numbers of TTGE bands indicate a limited number of species, i.e. only those microorganisms from the community which possess the highest competitive ability, are growing well. Environments with low nutrients lead to a more diverse species composition, and community shifts between the initial and the final state are less pronounced. Cultures kept in the light did not yield distinctly different patterns from those ones kept in the dark regardless whether they were grown with or without nutrient addition, except for the aerobic condition with no additional nutrients.

Certain bacterial communities develop different life strategies as an adaptation to various environmental conditions. Their population would be present predominantly even under markedly different environmental pressures which results in similar TTGE banding patterns. However, it cannot be ensured that those co-migrating bands have the same sequence identity. Therefore, it is helpful to identify the communities appearing in the TTGE bands. In this experiment, the representative TTGE bands of dominant communities were recovered and sequenced. The bands are phylogenetically affiliated to Alpha-, and Beta-Proteobacteria, Actinobacteria, chloroplasts, and candidates of division OP 10 (Figure 5). The communities are phylogenetically diverse and respond quickly to various environmental fluctuations.

Some sequences represented by bands A, B, C, 6 and 8, showed very low similarity values (86 to $94 \%$ sequence similarities) to known $16 \mathrm{~S}$ rDNA sequences of cultured bacteria present in the databank (Table 3). Cultivation efforts for those microorganisms could become valuable concerning their physiological properties.

The results suggest that community competition and adaptation processes are common in ecosystems exposed to strong physicochemical fluctuations. Physiological abilities of the microorganisms present in their gene pool allow the community to respond rapidly to environmental changes and thus ensure the functioning of microbially-mediated processes in the habitat. Microorganisms possessing a high physiological flexibility, so-called niche generalists, will dominate the population in their communities under various conditions (Elena and Sanjuan 2003), while niche specialists will get selected under more specific conditions. Environmental changes express themselves as physical and chemical instabilities, which exert selection pressures for different microorganisms. These changes promote the dynamic microbial community transitions in fluctuating environments (Rainey and Travisano 1998). 
added) rather than to NLO. Under low nutrient conditions, the majority of TTGE bands still appeared. Some became less intense after the two-week incubation period. A few bands are missing at the end of the experiment (e. g. bands A and B).

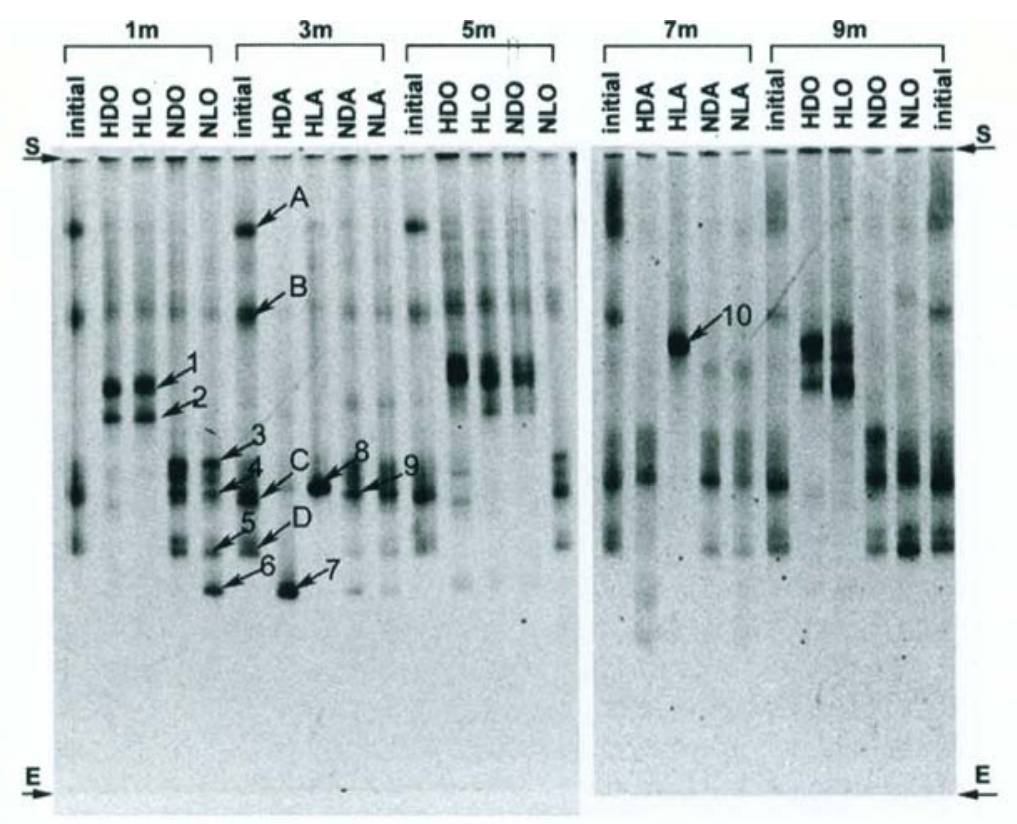

Figure 4. TTGE patterns of $16 \mathrm{~S}$ rDNA fragments amplified by nested PCR from total bacterial community DNA of Lake Jöri XIII from distinct depths incubated at different environmental conditions (except "initial").

Initial: initial population, before treatments were applied. H: 10-fold diluted LB medium added, N: no nutrients added, D: incubation in the dark, L: incubation in the light, A: anoxic condition, O: oxic condition. S: start of gels, E: end of gels.

The bacterial diversity decreases when the community is exposed to high nutrient concentrations and anoxic conditions. This can be detected from experiments designated HDA and HLA at depths of $3 \mathrm{~m}$ and $7 \mathrm{~m}$, respectively. In these treatments, light apparently is an essential determinant. In the light, bands 8 ( $3 \mathrm{~m}$ depth) and 10 ( $7 \mathrm{~m}$ depth) became prominent, in the dark, band 7 (3m depth). Based on NCBI-BLAST of 16S rRNA gene sequences, the closest known relative of band 7 (community exposed to HDA treatment) was an anaerobic, sulfate reducing bacterium, Desulfotomaculum sp. DEM-KMe99-2, AJ276565 (with 88\% sequence similarity). In the HLA culture, band 8 dominated the community, which is phylogenetically related to the alphaproteobacterium Sphingomonadaceae bacterium N, DQ497241 (99\% sequence similarity). The sequence of band 10 was closest related to the betaproteobacterium LI2-55 from Lake Loosdrecht water column, Netherlands, AJ964892 (97\% sequence similarity). 
Generally, it can be seen that incubations under high nutrient conditions showed fewer bands than the initial community and also fewer when compared to those without nutrients addition. Low numbers of TTGE bands indicate a limited number of species, i.e. only those microorganisms from the community which possess the highest competitive ability, are growing well. Environments with low nutrients lead to a more diverse species composition, and community shifts between the initial and the final state are less pronounced. Cultures kept in the light did not yield distinctly different patterns from those ones kept in the dark regardless whether they were grown with or without nutrient addition, except for the aerobic condition with no additional nutrients.

Certain bacterial communities develop different life strategies as an adaptation to various environmental conditions. Their population would be present predominantly even under markedly different environmental pressures which results in similar TTGE banding patterns. However, it cannot be ensured that those co-migrating bands have the same sequence identity. Therefore, it is helpful to identify the communities appearing in the TTGE bands. In this experiment, the representative TTGE bands of dominant communities were recovered and sequenced. The bands are phylogenetically affiliated to Alpha-, and Beta-Proteobacteria, Actinobacteria, chloroplasts, and candidates of division OP 10 (Figure 5). The communities are phylogenetically diverse and respond quickly to various environmental fluctuations.

Some sequences represented by bands A, B, C, 6 and 8, showed very low similarity values (86 to $94 \%$ sequence similarities) to known 16S rDNA sequences of cultured bacteria present in the databank (Table 3). Cultivation efforts for those microorganisms could become valuable concerning their physiological properties.

The results suggest that community competition and adaptation processes are common in ecosystems exposed to strong physicochemical fluctuations. Physiological abilities of the microorganisms present in their gene pool allow the community to respond rapidly to environmental changes and thus ensure the functioning of microbially-mediated processes in the habitat. Microorganisms possessing a high physiological flexibility, so-called niche generalists, will dominate the population in their communities under various conditions (Elena and Sanjuan 2003), while niche specialists will get selected under more specific conditions. Environmental changes express themselves as physical and chemical instabilities, which exert selection pressures for different microorganisms. These changes promote the dynamic microbial community transitions in fluctuating environments (Rainey and Travisano 1998). 

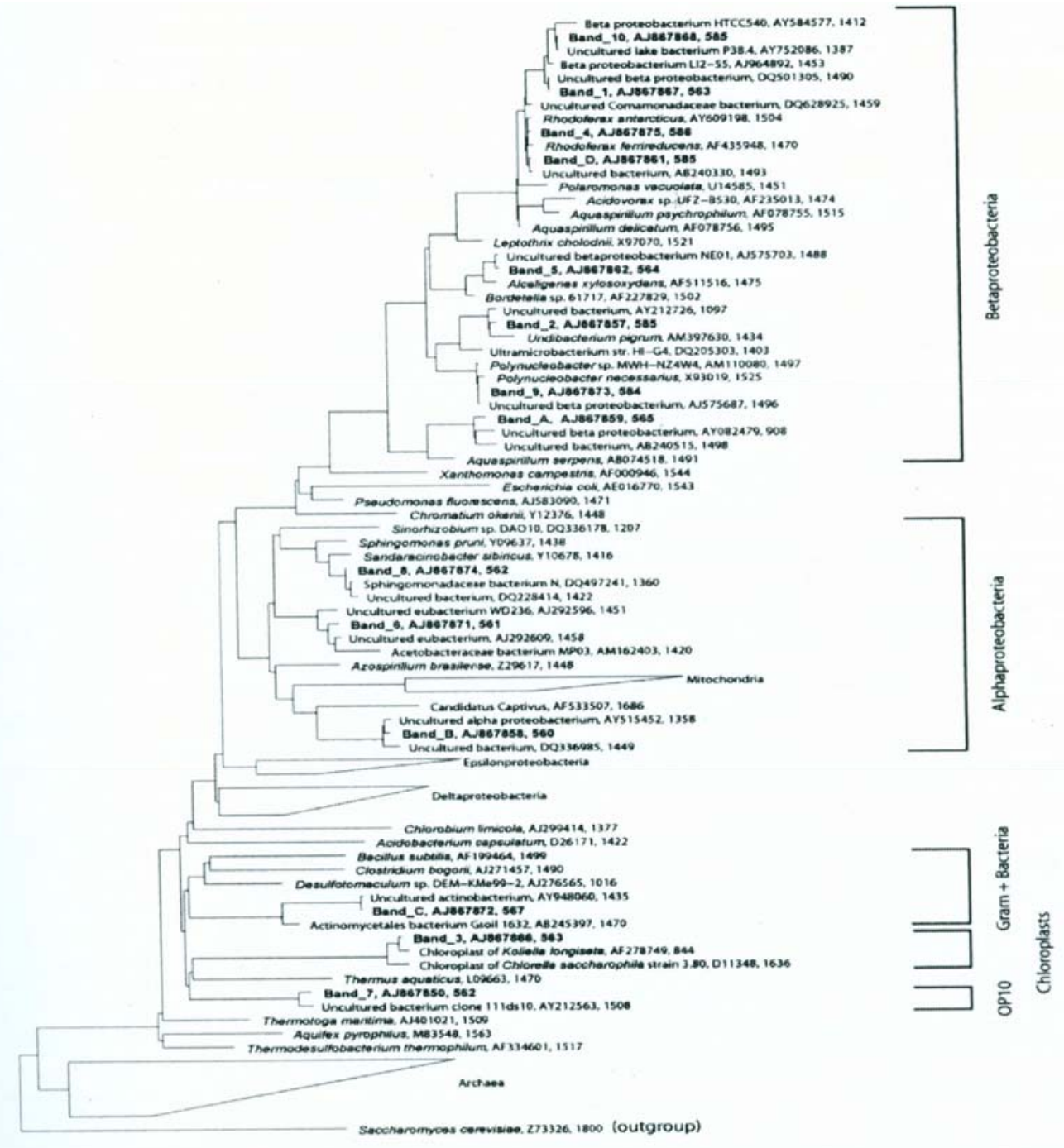

Figure 5. Phylogenetic affiliation of representative dominant TTGE bands of water samples from Lake Jori XI11 incubated at different environmental conditions. Nelv sequences are written in bold (Band_xx, accession no., length IbpJ). Closest known relatives are written in italic, followed by their accession nos. and sequence lengths (bp). A yeast 18S rRNA gene of Saccharomyces cerevisiae is used as outgroup. The scale bar indicates $10 \%$ sequence divergence 
Table 3. Identification of representative dominant TTGE bands of Lake Jöri XIII to their closest known relatives obtained from BLAST search from NCBI.

\begin{tabular}{|c|c|c|c|c|}
\hline $\begin{array}{c}\text { Band } \\
\text { designation }\end{array}$ & $\begin{array}{l}\text { Length } \\
\text { (bp) }\end{array}$ & Subgroup & Closest known species, accession no. & $\begin{array}{c}\% \\
\text { Similarity }\end{array}$ \\
\hline Band A & 565 & $\begin{array}{l}\text { Beta-Proteobacteria, } \\
\text { unclassified } \\
\text { Betaproteobacteria }\end{array}$ & $\begin{array}{c}\text { Ultramicrobacterium str. HI-G4, } \\
\text { DQ205303 }\end{array}$ & 91 \\
\hline Band B & 560 & $\begin{array}{l}\text { Alpha-Proteobacteria, } \\
\text { Rhizobiales }\end{array}$ & $\begin{array}{c}\text { Sinorhizobium sp. DAO10, } \\
\text { DQ336178 }\end{array}$ & 86 \\
\hline Band C & 567 & Actinobacteria & $\begin{array}{l}\text { Actinomycetales sp. strain Gsoil, } \\
\text { AB245397 }\end{array}$ & 91 \\
\hline Band D & 585 & $\begin{array}{l}\text { Beta-Proteobacteria. } \\
\text { Comamonadaceae }\end{array}$ & $\begin{array}{l}\text { Rhodoferax ferrireducens strain } \\
\text { DSM 15236, CP000267 }\end{array}$ & 98 \\
\hline Band 1 & 563 & $\begin{array}{l}\text { Beta-Proteobacteria, } \\
\text { Comamonadaceae }\end{array}$ & $\begin{array}{l}\text { Acidovorax sp. strain R-25076. } \\
\text { AM084035 }\end{array}$ & 97 \\
\hline Band 2 & 585 & $\begin{array}{l}\text { Beta-Proteobacteria, } \\
\text { Janthinobacteriaceae }\end{array}$ & $\begin{array}{l}\text { Cenibacterium arsenoxidans, } \\
\text { AY728038 }\end{array}$ & 97 \\
\hline Band 3 & 564 & Cloroplast organelles & $\begin{array}{l}\text { Chlorella saccharophila (strain } \\
\text { 3.80) chloroplast, D11348 }\end{array}$ & 97 \\
\hline Band 4 & 586 & $\begin{array}{l}\text { Beta-Proteobacteria, } \\
\text { Comamonadaceae }\end{array}$ & $\begin{array}{c}\text { Rhodoferax antarclicus strain } \\
\text { Fryxl, AY609198 }\end{array}$ & 97 \\
\hline Band 5 & 564 & $\begin{array}{l}\text { Beta-Proteobacteria, } \\
\text { Alcaligenaceae }\end{array}$ & $\begin{array}{l}\text { Bordetella sp. strain } 61717 \\
\qquad \text { AF227829 }\end{array}$ & 97 \\
\hline Band 6 & 561 & $\begin{array}{l}\text { Alpha-Proteobacteria, } \\
\text { Acetobacteraceae }\end{array}$ & $\begin{array}{l}\text { Acetobacteraceae bacterium MP03, } \\
\qquad \text { AM1 } 62403\end{array}$ & 94 \\
\hline Band 7 & 565 & $\begin{array}{l}\text { Clostridia, } \\
\text { Peptococcaceae }\end{array}$ & $\begin{array}{l}\text { Desulfotomaculum sp. DEM- } \\
\text { KMe99-2, AJ276565 }\end{array}$ & 88 \\
\hline Band 8 & 562 & $\begin{array}{l}\text { Alpha-Proteobacteria, } \\
\text { Sphingomonadaceae }\end{array}$ & $\begin{array}{l}\text { Sphingomonadaceae bacterium N, } \\
\text { DQ497241 }\end{array}$ & 99 \\
\hline Band 9 & 584 & $\begin{array}{l}\text { Beta-Proteobacteria, } \\
\text { Polynucleobacter }\end{array}$ & $\begin{array}{l}\text { Polynucleobacter sp. MWH- } \\
\text { NZ4W4, AM110080 }\end{array}$ & 99 \\
\hline Band 10 & 585 & $\begin{array}{l}\text { Beta-Proteobacteria, } \\
\text { Comamonadaceae }\end{array}$ & $\begin{array}{c}\text { Betaproteobacterium LI2-55, } \\
\text { AJ964892 }\end{array}$ & 97 \\
\hline
\end{tabular}

\section{CONCLUSIONS}

It is possible to follow the bacterial community shifts by applying the PCR-based molecular technique of Temporal Temperature Gradient Gel Electrophoresis (TTGE). The physicochemical determinants applied in the experiments triggered the changes in the bacterial community composition originating from a high mountai 
lake Jo'ri XIII. 16S rRNA gene sequencing and phylogenetic analysis revealed that the predominant populations are affiliated to the Alpha- and Beta- subgroups of the Proteobacteria, to Actinobacteria (high GC Gram + bacteria), chloroplasts and candidates of division OP 10.

\section{ACKNOWLEDGMENTS}

We are grateful to Hanne Grob, Ignachio Fernandez and Gabriela Iqbal-Nava for excellent technical assistance. We thank the reviewers for helpful comments on the article.

\section{REFERENCES}

Altschul, S.F, T.L. Madden, A.A. Schaffer, J. Zhang, Z. Zhang, W. Miller and DJ. Lipman. 1997. Gapped BLAST and PSI-BLAST: a new generation of protein database search programs. Nucleic Acids Res, 25: 3389-3402. Bosshard, P., R. Stettler and R. Bachofen. 2000. Seasonal and spatial community dynamics in the meromictic Lake Cadagno. Arch. Microbiol., 174: 168-174. Bothwell, M.L, D.M.J. Sherbot and C.M. Pollock. 1994. Ecosystem response to solar ultraviolet-B radiation: influence of trophic level interactions. Science, 265: 97-100. Casamayor, E.O, C. Pedrds-Alio, G. Muyzer and R. Amann. 2002. Microheterogeneity in 16 S ribosomal DNA-defmed bacterial populations from a stratified planktonic environment is related to temporal changes and to ecological adaptations. Appl. Environ. Microbiol., 68: 1706-1714. Elena, S.F. and R.

Sanjuan. 2003. Evolution: Climb Every Mountain? Science., 302: 2074-2075. Hollibaugh, J.T, P.S. Wong, N. Bano, S.K. Pak, E.M. Prager and C. Orrego. 2001. Stratification of microbial assemblages in Mono Lake, California, and response to a mixing event. Hydrobiologia., 466: 45-60. Iqbal-Nava, G. 2003. Microbial ecosystem evolution: biogeochemical nutrient scavenging is a prerequisite. Diploma Thesis, University of Basel, Switzerland. Lane, D.J. 1991. 16S/23S rRNA sequencing, p. 115-175. In E. Stackebrandt and M. Goodfellow (ed.), Nucleic acid techniques in bacterial systematics. John Wiley \& Sons Ltd., Chichester, United Kingdom. Ludwig, W., O. Strunk, R. Westram, L. Richter, H. Meier, Y. Kumar, A. Buchner, T. Lai, S. Steppi, G. Jobb, W. Forster, I. Brettske, S. Gerber, A.W. Ginhart, O. Gross, S. Grumann, S. Hermann, R. Jost, A. Konig, Th. Liss, R. LUBmann, M. May, B. Nonhoff, B. Reichel, R. Strehlow, A. Stamatakis, N. Stuckmann, A.Vilbig, M. Lenke, Th. Ludwig, A. Bode, and K.-H. Schleifer. 2004. ARB: a software environment for sequence data. Nucleic Acids Res, 32:1363-1371. Muyzer, G, B.C. de Waal and A.G. Uiterlinden. 1993. Profiling of complex microbial populations by denaturing gradient gel electrophoresis analysis of polymerase chain reaction-amplified genes coding for 16S rRNA. Appl. Environ. Microbiol., 59: 695-700. Muyzer, G. and K. Smalla. 1998. Application of denaturing gradient gel electrophoresis (DGGE) and temporal temperature gradient gel electrophoresis (TTGE) in microbial ecology. Antonie Leeuwenhoek, 73: 127-141. Muyzer, G, T. Brinkhoff, U. Niibel, C. Santegoeds, H. Schafer and C. Wawer. 1998. Denaturing gradient gel electrophoresis (DGGE) in microbial ecology, p. 1-27 In A. D. L. Akkermans, J. D. van Elsas, and F. J. de Bruijn (ed.), Molecular microbial ecology manual. Kluwer Academic Publishers, Dordrecht, The Netherlands. Muyzer, G. 1999. DGGE/TGGE, a method for identifying genes from natural ecosystems. Curr. Opin. Microbiol, 2: 317-322. Ogier, J.-C, O. Son, A. Gruss, P. Tailliez and A. Delacroix-Buchet. 2002. Identification of the bacterial microflora in dairy products by temporal temperature gradient gel electrophoresis. Appl. Environ. Microbiol, 68: 3691-3701. 
Pearce, D.A. 2000. A rapid, sensitive method for monitoring bacterioplankton community dynamics, applied to Atlantic freshwater lakes. Polar Biol. 23:352-356. Rainey, P.B. and M. Travisano. 1998. Adaptive radiation in a heterogeneous environment. Nature., 394:

69-72. Ward, D.M., R. Weller and M.M. Bateson. 1990. 16S rRNA sequences reveal numerous uncultured microorganisms in natural community. Nature, 345: 63-65. 